\title{
Sharia Cooperative Financial Inclusion And Entrepreneurial Orientation To Improve Sharia-Based Msme Empowerment New Normal Era In Malang City
}

\author{
Raisa Fitri ${ }^{1}$, Della Ayu Zonna Lia ${ }^{2}$,Aniek Murniati ${ }^{3}$ \\ ${ }^{1}$ Universitas Negeri Malang; Jalan Semarang 5, Malang. \\ ${ }^{3}$ Institut Teknologi dan Bisnis Asia, Jalan Rembuksari No. 1A, Malang

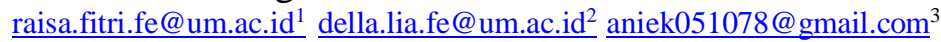

The problem that is faced by Islamic boarding school-based MSMEs is capital constraints. This capital constraint is due to the lack of information on MSME actors about how to apply for credit and how to utilize financing funds. Financial inclusion can be realized, there is a need for parties who have direct contact with the community, especially the lower middle class in terms of distributing micro credit. Therefore, the role of sharia banking and sharia cooperatives needs to be increased to increase the growth of MSMEs in Malang City, especially Sharia-based MSMEs so that financial inclusion can be realized. Based on the results of a survey conducted through the Cooperatives and MSMEs Offices, there are about 25 Sharia cooperatives with several criteria, namely cooperatives in Malang City that are legal entities. The multiple regression was chosen to be carried out in this research activity. The results of the study show that the good performance of an MSMEs can be seen from its entrepreneurial orientation because the increasing spirit of entrepreneurial orientation will motivate MSMEs to make innovations and be ready to face all possible risks in the future.

Keywords: Financial Inclusion, Sharia Cooperatives, MSMEs, Entrepreneurial Orientation

OPEN ACCESS

ISSN 2528-4649 (online)

ISSN 2338-4409 (print)

Reviewed by:

Dr. Nurul Qomariah, MM

${ }^{*}$ Correspondence: Raisa Fitri

raisa.fitri.fe@um.ac.id

Received: January 22, 2021

Accepted: February 28, 2021

diterima Published: March 31, 2021

JBMP: Jurnal Bisnis, Manajemen

dan Perbankan.

Vol: $7 /$ No. 1

doi: 10.21070/jbmp.v7i1.1226 


\section{INTRODUCTION}

Credit for MSMEs has increased annually due to support from banks that distribute loans to micro, small and medium enterprises (MSMEs). However, the role of Islamic financial institutions has not been optimal in terms of distributing MSMEs loans because of their relatively high costs (Anggraeni \& Herlinawati, 2019). In this case the government has the responsibility as a provider or channel of people's business credit or what is known by the acronym Kredit Usaha Rakyat (KUR) through Islamic banking which needs to be run. Sharia MSMEs players who need financial capital can go through Islamic banking and sharia-based institutions that collaborate with the government. According to Herijanto (2014) said that Islamic banking in East Java has given the Islamic banking funding in the amount of Rp243 trillion, with 26 percent of credit distribution to MSMEs. The growth of Sharia MSMEs in Indonesia is growing, one of the reason is because the majority of the population is Muslim (Q. N. Lahamid, 2018).

East Java Sharia Banking Assets in April 2018 increased by $19.25 \%$, which was supported by Dana Pihak Ketiga (DPK) funds of $19.45 \%$ and financing increased by $17.8 \%$. In 2018 and 2019 the government is trying to achieve the financing target for sharia MSMEs. Meanwhile, currently the portion of financing in the MSME sector by Islamic banking and Islamic cooperatives is relatively small, namely $30.49 \%$. To achieve the target, the government launched a program of Islamic financial access based on mosques and Islamic boarding schools (Otoritas Jasa Keuangan, 2018).

The development of Islamic banking and Islamic cooperatives in Indonesia is increasingly expanding, this will increase the development of the people in this country, that later the Islamic banking and Islamic cooperatives can bridge the realization of financial inclusion (Herijanto, 2014). As in Malaysia, it can be an innovation of global Islamic asset management products through the development of Islamic cooperatives because it is a non-traditional financial sector that has great potential to be absorbed into the Islamic financial industry.

All this time, sharia-based MSMEs are still hard in obtaining credit because the criteria for obtaining capital or credit financing are contrained by several factors such as business feasibility, account conditions in the last three months and the length of time the business has been established and the existence of collateral (Adawiyah, 2013). The various problems have become obstacles to the growth of MSMEs in Indonesia, such as the character of business actors who are less resilient, lack of business managerial in managing a business, and also a lack of innovation to deal with existing changes. (Herlinawati, Suryana, Ahman, \& Machmud, 2019).

Sharia banking needs to be even harder to collaborate with cooperatives to achieve the goal of developing Sharia MSMEs (Marlina \& Rahmat, 2018). Based on data from the OJK, in Malang, the demand for sharia-based financing is higher $(6.15 \%)$ when compared to the national average $(4.98 \%)$ (Otoritas Jasa Keuangan, 2018). The role of sharia cooperatives needs to be optimized in order to distribute financing to MSMEs so that later they can increase economic growth and improve entrepreneurial orientation among the community.

In realizing financial inclusion, parties who are in direct contact with society, especially the middle to lower class, are needed in terms of extending micro credit. The lower middleclass income groups have been familiar with the form of financial institutions such as sharia cooperatives are no stranger to society. The role of Islamic banking and Islamic cooperatives needs to be increased, the growth of MSMEs in Malang City especially Sharia-based MSMEs so that financial inclusion is realized. Based on the results of a survey conducted through the Cooperative and MSMEs Office, there are about 25 Sharia Cooperatives with several criteria, namely cooperatives in Malang City that are legal entities.

MSMEs that obtain credit from sharia-based financial institutions are known as Sharia MSMEs. One of them is the MSMEs which is located in the Islamic boarding school environment which has a role in developing sharia-based businesses and supporting food security programs. Meanwhile, the problem faced by Islamic boarding school-based MSMEs is capital constraints (Jenita, 2017; Q. Lahamid, 2018). This capital constraint is due to the lack of information on MSME actors about how to apply for credit and how to utilize financing funds. In addition to the above conditions, MSME actors also have obstacles in following the development of information technology which of course greatly affect their business. The low action and motivation of MSME actors, in average MSMEs actors only motivate to use their income to fulfill their daily needs without thinking about how to develop their business and how to innovate. This condition also requires the role of Sharia Cooperatives so as some MSMEs have pilot projects.

Some of the problems faced by MSMEs actors are required efforts to increase the empowerment of Sharia-based MSMEs, one of the programs that can help to improve the empowerment of Sharia MSMEs, namely through financial inclusion programs by the government and the importance of entrepreneurial orientation. The strong character of business actors and the spirit of always innovating are needed to increase entrepreneurial orientation.

\section{LITERATURE REVIEW}

\section{Sharia-based MSMEs}

Sharia-based MSMEs are MSMEs that obtain credit from sharia-based financial institutions or sectors. MSMEs that are located in Islamic boarding schools are an example that has a function in developing sharia-based businesses and supporting food security programs. Sharia MSMEs are managed based on Islamic sharia principles through productive economic activities for the community to improve the welfare of the society of the lower to middle class economy.

Sharia-based MSMEs in their business activities must comply with Islamic sharia principles which prohibit doing things that are maisir, gharar, and usury. The form of financing for sharia-based MSMEs is through sharia banking and sharia microfinance institutions. The resulting product has a halal certification and applies its business based on sharia principles (Q. Lahamid, 2018). 


\section{Sharia Cooperative as Financial Inclusion}

Sharia cooperatives apply principles in accordance with Islamic sharia and diversification from conventional cooperatives (Nawai \& Shafii, 2017). The foundation of establishment of a Sharia cooperative uses the concept of syirkah mufawadah where all parties involved contribute the same amount of funds and are involved in the management of the organization where profit and loss are divided equally among all members. In practice, cooperative members are not allowed to inject more funds and to receive a large share of the profits (Sofiana, 2014). The basic principle of Islamic cooperatives is strong cooperation between members. The annual member meeting is the highest forum where all strategic decisions are made. Each member has the right to vote and the same opportunity to convey ideas and opinions (Beik \& Purnamasari, 2011).

There are six main characteristics of sharia-based cooperatives, that are; 1) recognize the ownership rights of members over business capital; 2) forbid usury-based transactions; 3) ZISWAF institutions (zakat, infaq, sadaqah and waqf) function properly; 4) profit-oriented in accordance with sharia principles; 5) recognize freedom of doing business in business and the economy, and; 6) recognize mutual rights (Buchori, Harto, \& Wibowo, 2019).

In 2014, the government officially launched a financial inclusion program pioneered by Bank Indonesia (BI) for the implementation of public channels in obtaining financial services (Bank Indonesia, 2015). In pursuance of Nasution, Nasution, \& Yafiz (2017), the implementation of financial inclusion in this conventional case has been done, for example, giving Kredit Usaha Rakyat (KUR), development of Micro Finance Institutions in the form of Koperasi Jasa Simpan Pinjam (KSP) and Baitul Maal wa Tamwil (BMT).

Financial inclusion according to the Islamic view, the goal is to be able to collect and manage financial resources in accordance with sharia principles by improving the services of Islamic financial institutions to the wider community (Beik \& Arsyianti, 2016). Important benefits from the existence of a financial inclusion program are $\mathrm{t}$ alleviating poverty, to encourage the economic growth of a country and to minimize the social level that exists in society and to increase financial resilience (Soetiono \& Setiawan, 2019).

The financial inclusion program to alleviate poverty developed by the government is prioritized in people with low income because the financial inclusion program that has been implemented had not been optimal, as a result of the recipients of this program are not on target. Financial inclusion targeted at middle to lower income groups through microfinance institutions such as cooperatives requires a variety of efforts to realize this increase in financial inclusion, including:

Expanding the financial database of cooperative members related to the identity of cooperative members, the type of business that the member is running, potential members in terms of financial aspects, history of transactions with financial institutions, and various other relevant sources of information (Sinuraya, 2012).

Developing this database has an intention to record cooperative members so that each member has an identity card called an e-FIN (financial identity number). The e-FIN card can monitor each member of the cooperative in carrying out financial transactions both in cooperatives and in other finances institutions. The members benefit of being registered in the eFIN card are easier to get access to services in the form of loans according to their business needs, both from cooperatives, banks and other financial institutions.

To revitalize / rejuvenate cooperative institutions and cooperative businesses in a sustainable manner.

Cooperatives must have improved systems both in service and supervision so that they can be integrated with the national financial system, including banking.

\section{The Ability of Sharia Cooperatives to Empower MSMEs}

At this time Sharia Cooperatives in their services provide financing for MSMEs. Easy access that was owned by sharia cooperatives in providing collateral, determining rewards and providing facilities. In general, the existence of Islamic banks and Islamic cooperatives would serve MSMEs that did not get access to financing from conventional banks The results of the BI study contained in the results of previous research by Marimin \& Romdhoni (2017) stated that the potential for the development of Islamic banks by using BPRS and Islamic cooperatives to carry out principles in accordance with sharia as distribution of funds was very good. Even though the funds collected were quite small, the distribution of funds from Islamic bank sources was far more. Islamic banks is an intermediary institution channel funds according to sharia principles.

There are several strategies implemented by Islamic banking in increasing the empowerment of MSMEs, especially in terms of financing. As explained by Asiyah (2009) they are: 1) Creating strategic reforms in financing; 2) The existence of a Linkage Program that will link financing from sharia banks whose financing is greater to sharia microfinance institutions, for example BMT, BPRS, and sharia cooperatives so that they can directly reach groups of SMEs actors; 3) Pilot project; 4) Use of social funds; dan 5) Cooperation in terms of technical assistance.

\section{Entrepreneurial Orientation}

Entrepreneurial orientation is an individual predisposition to create innovation, actively and ready to accept all risks to start or manage a particular business (Luiz dos Santos \& Vieira Marinho, 2018; Naldi, Nordqvist, Hellerstedt, \& Wiklund, 2007; Yoon, Kim, \& Dedahanov, 2018). Entrepreneurial orientation is important because it relates to creative and innovative abilities and resources to find opportunities for business success. Entrepreneurship-oriented companies tend to be innovative, risk-taking and proactive (Asemokha, Musona, Torkkeli, \& Saarenketo, 2019; Cantaleano et al., 2018; Rezaei $\&$ Ortt, 2018). The results of research on entrepreneurial orientation generally use the dimensions of innovation, proactivity and risk taking as factors that affect business performance. The empirical findings also explain that companies that lead to entrepreneurship have far better performance than companies that do not lead to entrepreneurship (Covin, Green, \& Slevin, 2006).

Business actors in an effort to win the competition amidst rapid business changes are required to formulate the best 
concrete steps. According to Herlinawati et al. (2019), efforts to empower MSMEs are not only carried out in the local market but must be courageous and ready to face the global market.

The majority of SMEs in Indonesia's manufacturing sector are still concentrated in the local market. It is feared that SME products with low innovation, in the form of production results that tend to be stagnant, could endanger business sustainability. Constraints faced by SMEs, such as difficulties in marketing products, especially the lack of market information, low skill levels in technology and networking, have resulted in SMEs not being able to survive. The lack of mastery of skills in managing business finances, namely bookkeeping also resulted in bankruptcy. Even the results of the research also reveal that the majority of SMEs mix business capital with personal money (Anggraeni \& Herlinawati, 2019; Sari, 2013). This condition has an impact on unpreparedness to face competition in the global market.

In the manufacturing sector, the growth of MSMEs was currently hampered by various problems. This also hindered the success of the MSME business in Indonesia. This condition occurred because it was triggered by the character of the entrepreneur who was not yet strong and the presence of managerial who was considered weak in business management. In addition, the low innovation power in changing environmental conditions was also being the trigger.

MSMEs have excellent potential, however, the ability to improve performance and competitiveness in both the local and global markets was not balanced. Two previous research resulted by Machmud \& Ahman (2019) also Machmud, Nandiyanto, \& Dirgantari (2018) confirmed that the inability of MSMEs was assessed due to problems in the form of a lack of capital and access to capital to formal financial institutions. It also experienced difficulties in adapting to a dynamic environment, was less proactive in finding business opportunities, was less able to find new things to face various business challenges.

MSMEs are able to open opportunities that have not been found so far, on the other hand, they can also carry out management functions in line with the general theory of entrepreneurship. Entrepreneurial orientation will be easier to act and always driven to innovate, take risks, and be proactive (Walter, Auer, \& Ritter, 2006).

\section{METHOD (FOR RESEARCH ARTICLE)}

The research sample was carried out purposively at Sharia Cooperatives with several criteria, namely cooperatives in Malang City which are legal entities. Meanwhile, the sample of Sharia MSMEs is MSMEs based on Mosques and Islamic Boarding Schools in Malang City. Withdrawal of samples uses the Slovin method.

\section{Research Variable}

[Table 1 about here.]
Based on the table above, it can be developed to compile a questionnaire aimed at respondents. In general, five choice scales are provided with the following references: strongly agree (5), agree (4), less disagree (3), disagree (2), and strongly disagree (1). The multiple regression is chosen to be carried out in this research activity.

\section{Research Hypothesis}

Financial inclusion was one of the ways to socialize the financial line in order to provide easy services for the community, in this case, MSME actors. Efforts to expand financial inclusion were expected to be able to increase the empowerment of MSMEs. Research by Steelyana (2013) that the implementation of good financial inclusion will affect the performance of MSMEs as a whole, in line with the research by Marlina \& Rahmat (2018) that Islamic microfinance institutions such as cooperatives had a major role in encouraging the denomination of a nation through productive economic activities for the community to improve welfare. community life and also increase the empowerment of MSMEs. Based on the conditions described, the following are hypotheses that can be formulated.

H1: Financial inclusion has an effect on increasing the empowerment of Sharia-based MSMEs.

Besides of financial inclusion, entrepreneurial orientation also played a role in increasing the empowerment of MSMEs. According to research (Anggraeni \& Herlinawati, 2019) the good performance of an UMKM could be seen from its entrepreneurial orientation because the increasing spirit of entrepreneurial orientation fosters the motivation of MSME players to innovate and be ready to face any risks that may exist in the future. These are the hypothesis that can be formulated.

$\mathrm{H} 2$ : Entrepreneurial orientation has an effect on increasing the empowerment of Sharia-based MSMEs

H3: Financial inclusion and entrepreneurial orientation have an effect on increasing the empowerment of Sharia-based MSMEs

\section{Validity and Reliability Test}

The following are the test results in the table. 2 below it can be seen the value of the validity test of financial inclusion variables.

\section{[Table 2 about here.]}

Based on the table 2 above, the table shows the value of the validity test of the financial inclusion variable. The financial inclusion variable which consist of database developing and financial relevance can be stated valid with the corrected item-total correlation value $>0.3$. It means that database developing variable, institutional revalitation, financial system integration is the indicator of financial inclusion in New-normal era.

Reliability test indicated by the value of Cronbach's Alpha 
$>0,60$, which means that financial inclusion variable get high level of trust. Whereas the realibility is measured with Cronbach's Alpha which is presented in the table below with the value of 0.965 .

[Table 3 about here.]

In this study, entrepreneurial orientation is the $\mathrm{X} 2$ variable. Item in a research which include indicator of tendency to innovate, tendency to act positively, and tendency to take big risk based on Item-Total correlation value can be declared valid because the Item-Total correlation value of each question> 0.3. The following table shows the validity value of the entrepreneurial orientation variable.

[Table 4 about here.]

Cronbach Alpha Analysis can be used to do reliability test, through the way of keep paying attention to the value in Cronbach's Aplha $>0,60$. Value of Cronbach's Alpha can be seen in the Reliabelity Statistic Rable. Following above is the entrepreneurial orientation validity test table.

[Table 5 about here.]

In order to prove whether the questionnaire is valid or not, it can be proved from Item-Total Correlation. If R-count is bigger than the limit value, it means that the questionnaire declared valid. Through the table 5 , can be seen the value of Item-Total Correlation every question $>0,3$ which means that questionnaire declared valid.

Based on the explanation that have been delivered the questionnaire that related to entrepreneurial orientation declared valid. Based on result of study that has been done, research reliability value is 0,965 . Cronbach's Alpha's value $>0,60$, which means that the entrepreneurial orientation performance variable has a high level of trust.

Empowerment of MSMEs is the goal of this study to see how the performance of MSME empowerment in this study, so the validity test of the indicators that form the empowerment variables of MSMEs must be carried out.

[Table 6 about here.]

[Table 7 about here.]
Based on the results obtained from the validity and reliability test that the indicators that shape employee empowerment are valid and reliable, these results can be seen from the Item-Total Correlation (r-count) and Conbach's Alfa.

\section{Hyphothesis Test Result}

Financial inclusion can be attained with the aid of parties who have direct contact with the community, especially low middle-income class in term of extending micro credit. Financial inclusion program is expected to be able to increase empowerment of MSMEs. Efforts to socialize the financial sector through Sharia Cooperatives, which are expected to be able to touch businesses in the MSME sector. Information and technology development requires sharia cooperative to maximize their role especially in Malang City because of various kinds of MSMEs actors are available there. With the existing conditions, the researcher wants to know how the role of financial inclusion carried out by the government through sharia cooperatives will affect the performance of MSMEs in Malang City, especially Sharia-based MSMEs in Malang City in increasing the empowerment of MSMEs. The results of the research are shown by the results of statistical tests.

Entrepreneurial orientation is individual predisposition to create innovation, actively and prepared well to receive all the risk either to start or cultivate particular business (Luiz dos Santos \& Vieira Marinho, 2018; Naldi et al., 2007; Yoon et al., 2018). Information and Technology development actually will open MSMEs knowledge, motivation, and also creativity.

Based on this study, researcher wanted to examine the effect of the two variables, namely financial inclusion and entrepreneurial orientation to increase the empowerment of Islamic MSMEs in Malang City. Because the two variables are inseparable. The results of statistical tests on these variables can be seen in Table 8 below.

[Table 8 about here.]

Based on statistic test table which stated that either financial inclusion or entrepreneurial orientation do have significant positive impact. Based on the calculated $\mathrm{F}$ value (25.478) is greater than the calculated $F$ value (3.96) with a significance level of $0.00 \leq \alpha(0.05)$.

This study showed financial inclusion program which is obtained by government and do partnership with sharia cooperation and entrepreneurial orientation for all MSMEs actors is a suitable variable to increase empowerment Sharia MSMEs.

This means that this study shows that the financial inclusion program run by the government in collaboration with sharia cooperatives and entrepreneurial orientation for MSME actors is an appropriate variable to increase the empowerment of Islamic MSMEs. The suitability of the financial inclusion variable model and entrepreneurial orientation on the empowerment of MSMEs is $75.3 \%$ as shown in the R Square table. 
[Table 9 about here.]

Based on the $\mathrm{R}$ square statistic test result, it is known that the suitability of the model is $75,3 \%$ where the financial inclusion program which run by government collaborate with sharia MSMEs and company orientation to all MSMEs actors are suitable variable to increase empowerment of sharia MSMEs. While sharia MSMEs performance is $24,7 \%$ influenced by other variables.

\section{DISCUSSION}

As mentioned in the literature review, sharia cooperative implement principles in accordance with Islam and are diversification from conventional cooperatives (Nawai \& Shafii, 2017). Financial inclusion according to the Islamic sight is having an intention to collect and manage financial sources in accordance with sharia principle through improving sharia financial institution service to the wider community (Beik \& Arsyianti, 2016).

Services to community by means of empowerment MSMEs can be touched through financial inclusion. With technology development, sharia cooperatives which implement financial inclusion are trying to develop or empower MSMEs. As how sharia cooperatives in Malang city, which try to empower MSMEs. Empowerment of MSMEs is not sufficiently influenced by capital or financing factors, but there must be an entrepreneurial spirit for the perpetrators / entrepreneurial orientation.

As the result of current study about entrepreneurial orientation and financial inclusion according to research (Hidayat dan Purwidiarti, 2016) that good performance from the MSMEs can be seen from their entrepreneurial orientation because with the increasing spirit of entrepreneurial orientation it fosters the motivation of MSME players to innovate and be ready to face all possible risks. In line with the research (Marlina dan Rahmat, 2018) that micro sharia financial institution similar to cooperatives has a crucial role to encouraging the denomination of a nation through productive economic activities for the community to improve people's welfare and also increase the empowerment of MSMEs.

In order to increase empowerment sharia MSMEs, sharia cooperatives in Malang City have placed proper and competent human resources in implementing sharia principles, developing the implementation of potential financial database efficiently, and implementing e-FIN system to make it easier to obtain service access to cooperatives member. Moreover, the financial inclusion implementation has to be supported by the motivation of entrepreneurial actors itself. In Malang City, MSMEs actors have high entrepreneurial orientation as proved with the increasing of work performance. One of several factors that encourage MSMEs are the availability of clear market share and also the addition of knowledge in the form of joining entrepreneurial training either in the production sector or marketing sector which is held by private sector or local government.

Entrepreneurial practice which was attended by some participants can build entrepreneurial spirit for MSMEs actors, with those training, it is hoped that can trigger entrepreneurial orientation, thus the awareness of looking for maisyah is the form of praying. The result of this study indicates financial literation in Malang City increase in the end of 2019 (Pradana, 2019). In 2020 during the COVID-19 pandemic in 2020 during the Covid-19 pandemic there was a weakening of economic activity which affected the emphasis on the financial performance of cooperatives which had an impact on the empowerment of MSMEs. In this condition, government with cooperatives and other financial institution do activities which called bulan inklusi keuangan, which require every institution including cooperative to give tagline: "Maju Berkat Pembiayaan". With a proper level of knowledge and understanding of the community regarding products and services according to their abilities in economic activities, it will increase the empowerment of MSMEs.

\section{CONCLUSION}

The development of sharia financial sector in Indonesia is gradually starting to have significant impact to the development of economic in a country. One of the sharia economic branch which have carried out is sharia cooperatives. One interesting finding in this study is can be concluded that financial inclusion program which is held by government through sharia cooperative will give impact on MSMEs performance in Malang City especially MSMEs sharia-based. Moreover, in running its business, sharia cooperatives in Malang City need to develop and increase the entrepreneurial orientation. Because based on previous study and the results of this study prove that entrepreneurial orientation plays a central role in the success of a particular business / business.

As the covid-19 pandemic persists, the sharia financial sector needs to be implemented as an effort to breathe new life into efforts to improve the country's economy. Through the sharia cooperative sector, with qualified human resources relevant to the needs of the field, providing easy capital credit and in accordance with sharia principles, will assist the government in efforts to improve the country's economy through the sharia financial sector.

\section{SUGGESTION}

Future research is expected to examine the effect of entrepreneurial orientation on the performance of MSMEs. In addition, it is necessary to add a variable financial literacy in supporting financial inclusion that is run by the government in collaboration with other sharia-based financial sectors such as Islamic rural banks, Islamic capital markets, and sharia insurance. 


\section{REFERENCES}

Adawiyah, W. R. (2013). Faktor Penghambat Pertumbuhan Usaha Mikro Kecil Menengah (UMKM): Studi di Kabupaten Banyumas. Sustainable Competitive Advantage (SCA), 1(1). Retrieved from http://jp.feb.unsoed.ac.id/index.php/sca1/article/view/134

Anggraeni, D., \& Herlinawati, E. (2019). Analisis Model Pembiayaan Umkm Melalui Peran Lembaga Keuangan Mikro. Image : Jurnal Riset Manajemen, 8(1), 21-27. doi: 10.17509/image.v8i1.23117

Asemokha, A., Musona, J., Torkkeli, L., \& Saarenketo, S. (2019). Business model innovation and entrepreneurial orientation relationships in SMEs: Implications for international performance. Journal of International Entrepreneurship, 17(3), 425-453. doi: 10.1007/s10843-019-00254-3

Asiyah, S. (2009). PEMBERDAYAAN USAHA KECIL DAN MENENGAH (UKM) MELALUI POLA PEMBIAYAAN SYARIAH BERBASIS KEARIFAN LOKAL. JAMSWAP, 1(1), 44-51.

Bank Indonesia. (2015). Keuangan Inklusif. Retrieved 31 January 2021, from Bank Indonesia website: https://www.bi.go.id/id/fungsi-utama/stabilitas-sistem-keuangan/keuangan-inklusif/Default.aspx

Beik, I. S., \& Arsyianti, L. D. (2016). MEASURING ZAKAT IMPACT ON POVERTY AND WELFARE USING CIBEST MODEL. Journal of Islamic Monetary Economics and Finance, 1(2), 141-160. doi: 10.21098/jimf.v1i2.524

Beik, I. S., \& Purnamasari, I. (2011). Empirical Role of Islamic Cooperatives in Financing Micro and Small Scale Entrepreneurs in Indonesia: Case Study of KOSPIN Jasa Syariah Pekalongan - Islamic Economics \& Finance Pedia. Presented at the 8th International Conference on Islamic Economics and Finance, Doha - Qatar. Retrieved from http://www.iefpedia.com/english/?p=6367

Buchori, Nur. S., Harto, P. P., \& Wibowo, H. (2019). Manajemen Koperasi Syariah: Teori dan Praktik. Depok: PT. RajaGrafindo Persada.

Cantaleano, K. R., Rodrigues, G. P., Martins, T. S., Cantaleano, K. R., Rodrigues, G. P., \& Martins, T. S. (2018). THE MEDIATING EFFECT OF PROACTIVE MARKET ORIENTATION CAPABILITY IN ENTREPRENEURIAL ORIENTATION AND SERVICE INNOVATION. RAM. Revista de Administração Mackenzie, 19(1). doi: 10.1590/16786971/eramr 180038

Covin, J. G., Green, K. M., \& Slevin, D. P. (2006). Strategic Process Effects on the Entrepreneurial Orientation-Sales Growth Rate Relationship. Entrepreneurship Theory and Practice, 30(1), 57-81. doi: 10.1111/j.1540-6520.2006.00110.x

Herijanto, H. (2014). Selamatkan Perbankan Demi Perekonomian Indonesia. Expose. Retrieved from https://openlibrary.telkomuniversity.ac.id/pustaka/30512/selamatkan-perbankan-demi-perekonomian-indonesia.html

Herlinawati, E., Suryana, Ahman, E., \& Machmud, A. (2019). The effect of entrepreneurial orientation on smes business performance in Indonesia. Journal of Entrepreneurship Education, 22(5).

Jenita, J. (2017). PERAN LEMBAGA KEUANGAN MIKRO SYARIAH DALAM PEMBERDAYAAN EKONOMI MASYARAKAT KECIL MENENGAH. Al-Masraf : Jurnal Lembaga Keuangan dan Perbankan, 2(2), 177-191. doi: 10.15548/almasraf.v2i2.136

Lahamid, Q. (2018). Hambatan dan Upaya UMKM Kreatif Menjalankan Usaha Berbasis Syariah di Kota Pekanbaru. Sosial Budaya, 15(1), 27-36. doi: 10.24014/sb.v15i1.4992

Lahamid, Q. N. (2018). Hambatan Dan Upaya Usaha Mikro Kecil Menengah (UMKM) Kreatif Berbasis Syariah Di Kota Pekanbaru. Sosial Budaya, 15(1), 27.

Luiz dos Santos, I., \& Vieira Marinho, S. (2018). Relationship between entrepreneurial orientation, marketing capability and business performance in retail supermarkets in Santa Catarina (Brazil). Innovation \& Management Review, 15(2), 118-136. doi: 10.1108/INMR-04-2018-008

Machmud, A., \& Ahman, E. (2019). Effect of entrepreneur psychological capital and human resources on the performance of the catering industry in indonesia. Journal of Entrepreneurship Education, 22.

Machmud, A., Nandiyanto, A., \& Dirgantari, P. (2018). Technical efficiency chemical industry in indonesia: Stochastic frontier analysis (SFA) approach. Pertanika Journal of Science and Technology, 26, 1453-1464.

Marimin, A., \& Romdhoni, A. H. (2017). PERKEMBANGAN BANK SYARIAH DI INDONESIA. Jurnal Ilmiah Ekonomi Islam, 1(02). doi: 10.29040/jiei.v1i02.30

Marlina, L., \& Rahmat, B. Z. (2018). Peran Lembaga Keuangan Syariah Dalam Mengimplementasikan Keuangan Inklusif Bagi Pelaku UMKM Tasikmalaya. Jurnal Ecodemica: Jurnal Ekonomi, Manajemen, dan Bisnis, 2(1), 125-135. (Keuangan Syariah, Ekonomi Islam).

Mustikowati, R. I., \& Tysari, I. (2014). ORIENTASI KEWIRAUSAHAAN, INOVASI, DAN STRATEGI BISNIS UNTUK MENINGKATKAN KINERJA PERUSAHAAN (STUDI PADA UKM SENTRA KABUPATEN MALANG). Jurnal Ekonomi Modernisasi, 10(1), 23-37. doi: 10.21067/jem.v10i1.771

Naldi, L., Nordqvist, M., Hellerstedt, K., \& Wiklund, J. (2007). Entrepreneurial Orientation, Risk Taking, and Performance in Family Firms. Family Business Review, 20. doi: 10.1111/j.1741-6248.2007.00082.x

Nasution, H., Nasution, Y., \& Yafiz, M. (2017). ANALISIS FINANCIAL INCLUSION TERHADAP PEMBERDAYAAN MASYARAKAT MISKIN DI MEDAN (STUDI KASUS PEMBIAYAAN MIKRO SS II DI BANK SUMUT SYARIAH). 
JURNAL EKONOMI DAN BISNIS ISLAM, 2(1). doi: 10.32505/jebis.v2i1.119

Nawai, N., \& Shafii, Z. (2017). Understanding Islamic Cooperatives Mechanisms for The Accessibility Promotion of Islamic Finance in Malaysia. Journal of Islamic Philanthropy \& Social Finance, 1(1), 1-13.

Otoritas Jasa Keuangan. (2018). LAPORAN PERKEMBANGAN KEUANGAN SYARIAH INDONESIA 2017. OTORITAS JASA KEUANGAN. Retrieved from OTORITAS JASA KEUANGAN website: https://www.ojk.go.id/id/berita-dankegiatan/publikasi/Documents/Pages/Laporan-Perkembangan-Keuangan-Syariah-

2017/Laporan\%20Perkembangan\%20Keuangan\%20Syariah\%20Indonesia\%20(LPKSI)\%202017\%20\%20(final).pdf

Pradana, R. S. (2019). Faktor-Faktor yang Mempengaruhi Preferensi Penggunaan E-money di Kota Malang Ramandhika Surya Pradana. Jurnal Ilmiah Mahasiswa FEB, 7(2). Retrieved from https://jimfeb.ub.ac.id/index.php/jimfeb/article/view/5912

Rezaei, J., \& Ortt, R. (2018). Entrepreneurial orientation and firm performance: The mediating role of functional performances. Management Research Review, 41(7), 878-900. doi: 10.1108/MRR-03-2017-0092

Sari, D. P. (2013). TELISIK PERLAKUAN TEORI ENTITAS USAHA MIKRO, KECIL DAN MENENGAH. Jurnal Akuntansi Multiparadigma, 4(2), 188-197. doi: 10.18202/jamal.2013.08.7192

Sinuraya, R. E. (2012). Dialog Antara Prinsip-Prinsip dan Nilai-Nilai Koperasi dengan Modal Sosial di Koperasi Kredit Marsudi Mulyo, Putat Patuk Gunung Kidul. JKAP (Jurnal Kebijakan Dan Administrasi Publik), 16(1), 73-88. doi: 10.22146/jkap.8037

Soetiono, K. S., \& Setiawan, C. (2019). Literasi dan Inklusi Keuangan Indonesia. Rajawali Pers.Retrieved fromhttps://openlibrary.telkomuniversity.ac.id/pustaka/150479/literasi-dan-inklusi-keuangan-indonesia.html

Sofiana, T. (2014). KONSTRUKSI NORMA HUKUM KOPERASI SYARIAH DALAM KERANGKA SISTEM HUKUM KOPERASI NASIONAL. JURNAL HUKUM ISLAM. doi: 10.28918/jhi.v1i1.535

steelyana w, E. (2013). Perempuan dan Perbankan: Sebuah Tinjauan Tentang Peran Inklusi Keuangan terhadap Pengusaha UMKM Perempuan di Indonesia. The Winners, 14, 95. doi: 10.21512/tw.v14i2.649

Walter, A., Auer, M., \& Ritter, T. (2006). The Impact of Network Capabilities and Entrepreneurial Orientation on University Spin-Off Performance. Journal of Business Venturing, 21, 541-567. doi: 10.1016/j.jbusvent.2005.02.005

Yoon, J., Kim, K., \& Dedahanov, A. (2018). The Role of International Entrepreneurial Orientation in Successful Internationalization from the Network Capability Perspective. Sustainability, 10(6), 1709. doi: 10.3390/su10061709

Conflict of Interest Statement: The authors declare that the research was conducted in the absence of any commercial or financial relationships that could be construed as a potential conflict of interest.

Copyright $($ tahun terbit nama belakang and nama belakang. This is an openaccess article distributed under the terms of the Creative Commons Attribution License $(C C B Y)$. The use, distribution or reproduction in other forums is permitted, provided the original author(s) and the copyright owner(s) are credited and that the original publi-cation in this journal is cited, in accordance with accepted academic practice. No use, distribution or reproduction is permitted which does not comply with these terms. 


\section{LIST OF TABLES}

1 Blue Print

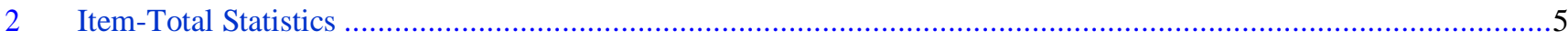

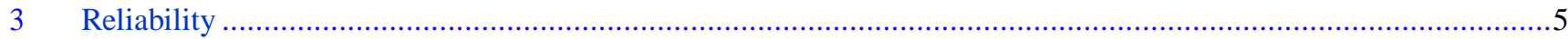

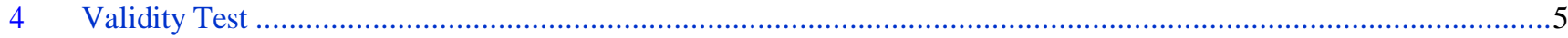

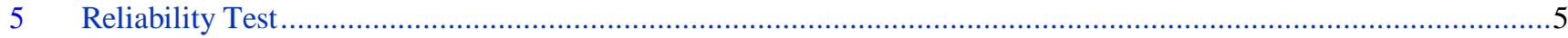

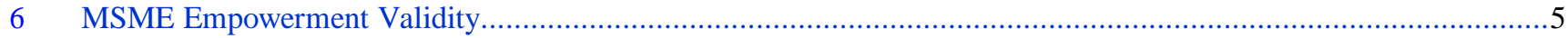

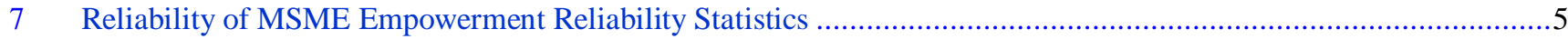

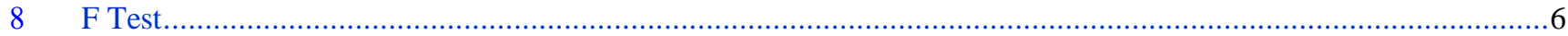

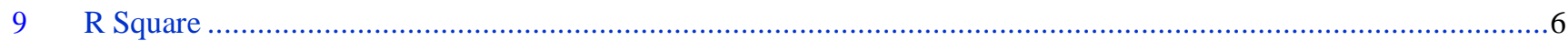




\begin{tabular}{|c|c|c|}
\hline No & Variable & Indicator \\
\hline 1 & Financial Inclusion & $\begin{array}{l}\text { 1.1 Expansion of the financial potential database } \\
\text { 1.2. Revitalizing cooperative entities and businesses } \\
\text { 1.3. Financial system integration }\end{array}$ \\
\hline 2 & $\begin{array}{c}\text { Entrepreneurial } \\
\text { orientation }\end{array}$ & $\begin{array}{l}\text { 2.1 Tendency to innovate (innovativeness) } \\
\text { 2.2 Tendency to act proactively (proactiveness) } \\
\text { 2.3 Ability to face risks (risk taking) }\end{array}$ \\
\hline 3 & $\begin{array}{c}\text { Empowerment of } \\
\text { MSMEs }\end{array}$ & $\begin{array}{l}\text { 3.1 Innovation financing strategy } \\
\text { 3.2 Beneficiary of social funds } \\
\text { 3.3 Pilot Project }\end{array}$ \\
\hline
\end{tabular}


TABLE 2 / Item-Total Statistics

Item-Total Statistics

\begin{tabular}{|l|r|r|r|r|}
\hline & $\begin{array}{c}\text { Scale Mean if } \\
\text { Item Deleted }\end{array}$ & $\begin{array}{c}\text { Scale } \\
\text { Variance if } \\
\text { Item Deleted }\end{array}$ & $\begin{array}{c}\text { Corrected Item- } \\
\text { Total } \\
\text { Correlation }\end{array}$ & $\begin{array}{c}\text { Cronbach's } \\
\text { Alpha if } \\
\text { Item Deleted }\end{array}$ \\
\hline X1.1 & 34,13 & 25,347 &, 963 &, 967 \\
X1.2 & 34,30 & 27,148 &, 836 &, 986 \\
X1.3 & 34,29 & 27,409 &, 836 &, 972 \\
X1.4 & 34,37 & 27,064 &, 826 &, 976 \\
X1.5 & 34,27 & 29,075 &, 799 &, 988 \\
X1.6 & 34,15 & 29,645 &, 647 &, 976 \\
X1.7 & 34,27 & 29,313 &, 858 &, 935 \\
X1.8 & 34,17 & 29,313 &, 838 &, 965 \\
X1.9 & 34,17 & 29,313 &, 838 &, 935 \\
\hline
\end{tabular}


TABLE 3 / Reliability

\section{Reliability Statistics}

\begin{tabular}{|c|c|c|}
\hline Cronbach's Alpha & $\begin{array}{c}\text { Cronbach's Alpha } \\
\text { Based on } \\
\text { Standardized } \\
\text { Items }\end{array}$ & N of Items \\
\hline, 965 &, 965 & 9 \\
\hline
\end{tabular}


TABLE 4 / Validity Test

\begin{tabular}{|l|r|r|r|r|}
\hline & $\begin{array}{c}\text { Scale Mean if Item } \\
\text { Deleted }\end{array}$ & $\begin{array}{c}\text { Scale } \\
\text { Variance if } \\
\text { Item } \\
\text { Deleted }\end{array}$ & $\begin{array}{c}\text { Corrected } \\
\text { Item-Total } \\
\text { Correlation }\end{array}$ & $\begin{array}{c}\text { Cronbach's } \\
\text { Alpha if Item } \\
\text { Deleted }\end{array}$ \\
\hline X2.1 & 33,00 & 41,793 &, 785 &, 986 \\
X2.2 & 33,03 & 40,792 &, 917 &, 982 \\
X2.3 & 33,03 & 39,826 &, 910 &, 982 \\
X2.4 & 33,07 & 39,030 &, 961 &, 980 \\
X2.5 & 33,07 & 39,582 &, 817 &, 986 \\
X2.6 & 33,10 & 38,990 &, 985 &, 979 \\
X2.7 & 33,10 & 38,990 &, 985 &, 979 \\
X2.8 & 33,10 & 38,990 &, 985 &, 979 \\
X2.9 & 33,10 & 38,990 &, 985 &, 979 \\
\hline
\end{tabular}


TABLE 5 / Reliability Test

\section{Reliability Statistics}

\begin{tabular}{|r|c|r|}
\hline & Cronbach's & \\
& Alpha Based & \\
& on & \\
Cronbach's Alpha & Items & N of \\
Items \\
\hline, 983 &, 984 & 9 \\
\hline
\end{tabular}


TABLE 6 / MSME Empowerment Validity

Item-Total Statistics

\begin{tabular}{|l|r|r|r|r|}
\hline & \multicolumn{1}{|c|}{$\begin{array}{c}\text { Scale } \\
\text { Mean if } \\
\text { Item } \\
\text { Deleted }\end{array}$} & $\begin{array}{c}\text { Scale } \\
\text { Variance if } \\
\text { Item } \\
\text { Deleted }\end{array}$ & $\begin{array}{c}\text { Corrected } \\
\text { Item- } \\
\text { Total } \\
\text { Correlatio } \\
\text { n }\end{array}$ & $\begin{array}{c}\text { Cronbac } \\
\text { h's } \\
\text { Alpha if } \\
\text { Item } \\
\text { Deleted }\end{array}$ \\
\hline Y1.1 & 34,60 & 93,007 &, 803 &, 394 \\
Y1.2 & 34,60 & 93,007 &, 709 &, 394 \\
Y1.3 & 34,43 & 100,047 &, 298 &, 446 \\
Y1.4 & 34,63 & 103,275 &, 759 &, 470 \\
Y1.5 & 34,40 & 98,248 &, 463 &, 431 \\
Y1.6 & 34,57 & 93,151 &, 880 &, 396 \\
Y1.7 & 34,60 & 93,007 &, 706 &, 394 \\
Y1.8 & 34,60 & 93,007 &, 703 &, 394 \\
Y1.9 & 33,17 & 31,178 &, 514 &, 940 \\
\hline
\end{tabular}


TABLE 7 / Reliability of MSME Empowerment Reliability Statistics

\begin{tabular}{|r|r|r|}
\hline & $\begin{array}{c}\text { Cronbach's } \\
\text { Alpha Based on } \\
\text { Standardized } \\
\text { Items }\end{array}$ & $\begin{array}{c}\text { N of } \\
\text { Items }\end{array}$ \\
\hline, 466 &, 996 & 9 \\
\hline
\end{tabular}


TABLE 8 / F Test

\begin{tabular}{|c|c|c|c|c|c|c|}
\hline \multicolumn{7}{|c|}{ ANOVA $^{a}$} \\
\hline & & $\begin{array}{l}\text { Sum of } \\
\text { Squares }\end{array}$ & Df & Mean Square & $\mathrm{F}$ & Sig. \\
\hline \multirow[t]{3}{*}{1} & Regression & 1838,171 & 2 & 919,086 & 25,478 &, $000^{\mathrm{b}}$ \\
\hline & Residual & 1212,129 & 27 & 44,894 & & \\
\hline & Total & 3050,300 & 29 & & & \\
\hline
\end{tabular}

a. Dependent Variable: Y

b. Predictors: (Constant), X2, X1 
TABLE $9 \mid R$ Square

\begin{tabular}{|c|c|c|c|c|}
\hline Model & $\mathrm{R}$ & R Square & $\begin{array}{c}\text { Adjusted R } \\
\text { Square }\end{array}$ & $\begin{array}{l}\text { Std. Error of } \\
\text { the Estimate }\end{array}$ \\
\hline 1 &, $786^{\mathrm{a}}$ & ,753 & ,573 & 6,700 \\
\hline
\end{tabular}

a. Predictors: (Constant), X2, X1

b. Dependent Variable: Y 